\title{
Overcoming smallness: Qatar, the United Arab Emirates and strategic realignment in the Gulf
}

\author{
Rory Miller ${ }^{1} \cdot$ Harry Verhoeven ${ }^{1}$
}

Published online: 20 May 2019

(c) The Author(s) 2019

\begin{abstract}
Geography and the anarchic state system incentivise the United Arab Emirates (UAE) and Qatar to collaborate in managing the threat posed by being neighbours of two (aspiring) regional hegemons, Saudi Arabia and Iran. However, both small states have responded very differently to the causes and consequences of instability in the Gulf region and developed very different foreign policies to deal with their structural IR problem. Just how divergent their external relations now are is clearly seen in the UAE's lead role in the diplomatic boycott and economic embargo launched against Qatar in June 2017-including the de facto dissolution of the Gulf Cooperation Council. Framing our examination in the theoretical literature on small states, we explain the ultimately colliding foreign policy trajectories of the UAE and Qatar in terms of diverging ideational and strategic considerations in the cause of what we term 'overcoming smallness'.
\end{abstract}

Keywords Al Jazeera $\cdot$ Foreign policy $\cdot$ Gulf politics $\cdot$ Regional security $\cdot$ Regional order $\cdot$ Small states

\section{Introduction}

Since June 2017, the United Arab Emirates (UAE) in partnership with Saudi Arabia has led a coalition of states including Egypt and Bahrain in a diplomatic boycott and economic embargo of Qatar. Before the outbreak of the crisis, these small but influential allies of the USA had been involved in squabbles on a whole range of foreign policy issues. Most notably, they found themselves on opposing sides during the Arab Spring over the 2011 revolution in Egypt, the rise of the Muslim Brotherhood and the future of post-Qaddafi Libya. In March 2014, these differences resulted

Harry Verhoeven

Hv89@georgetown.edu

Rory Miller

Rdm81@georgetown.edu

1 School of Foreign Service in Qatar, Georgetown University, Education City, PO Box 23689,

Doha, Qatar 
in the UAE joining Saudi Arabia and Bahrain in briefly withdrawing its ambassador from Doha. Then, as in 2017, the UAE not only placed itself squarely on the side of Saudi Arabia in its long-running confrontation with Qatar, but played a catalytic role, according to insider accounts, in encouraging Riyadh's unforgiving stance visà-vis Doha. This positioning exposed the deep cleavages between the Qatari and Emirati visions for the wider Middle East.

These tensions might seem surprising, and their intensity was predicted by few as recently as a decade ago. Structurally, Qatar and the UAE face a near-identical International Relations challenge: as small states bordering two aspiring regional hegemons, Iran and Saudi Arabia, with whom they both have border disputes, one could reasonably expect them to pursue similar foreign policies that seek to safeguard their sovereignty and expand their autonomy vis-à-vis Tehran and Riyadh. Geography and the anarchic state system incentivise Doha and Abu Dhabi to collaborate, yet what is striking is just how differently they have responded to the causes and consequences of regional instability in the Middle East and how divergent their external relations now are.

From the late 1990s until the Arab Spring, the UAE's priority was to consolidate economic sovereignty and establish itself as the leading economic actor in the Gulf. Qatar prioritised the consolidation of political sovereignty and strove to become a key diplomatic player in the wider Arab world. In pursuit of these parallel and, at times, overlapping interests they cooperated regularly, often acting together inside the Gulf Cooperation Council (GCC), to close the power gap with Saudi Arabia, home to the Arab Gulf's largest population, economy and army, most of its oil and its most conservative rulers.

During the mid-1970s, for example, Saudi Arabia pressured the UAE into a treaty in which the fledgling federation abandoned its claim to the Zararah oilfield on their shared border and surrendered the only piece of land that linked it to Qatar. Three decades later, in a highly symbolic move that was staunchly opposed by Riyadh, the UAE and Qatar used the annual GCC leaders' summit to announce their agreement to build a causeway over the Khor al-Odeid waters. If completed, this would have allowed them to bypass Saudi territory, demonstrating their independence from their larger neighbour.

Such subtle efforts to balance Riyadh's hegemonic aspirations via the GCC and mitigate the constraints of smallness have been complemented, especially since the Iraqi invasion of Kuwait in 1990, by a more straightforward strategy based on bilateral military partnerships with the USA. This has provided Doha and Abu Dhabi with assurances that any moves by larger regional actors, notably revolutionary Iran, to militarise differences, would be met with overwhelming force.

The Arab Spring provided the environment for a dramatic acceleration in the foreign policy ambitions of both states: no longer merely managing smallness but seeking to overcome it. Both were at the 'forefront' of attempts to 'control and shape the direction of the changes coursing through the Arab world'. ${ }^{1}$ The UAE became

\footnotetext{
1 Ulrichsen, K.C. (2012) Small states with a big role: Qatar and the United Arab Emirates in the wake of the Arab Spring Durham University, HH Sheikh Nasser al Mohammad al Sabah Publication Series, 3, 13, Oct https://www.dur.ac.uk/resources/alsabah/al-SabahPaperUlrichsenno3.pdf. Accessed 25 March 2018
} 
preoccupied with expanding its role as a security actor able to project military power to accompany its mercantile prowess and increasingly it looked beyond the Gulf to do so. This made alignment with Riyadh on essential foreign policy issues a central component of its strategic vision as its former preoccupation with economic competition with the Saudi neighbour waned in importance. ${ }^{2}$ Qatar ambitiously looked to reduce further the power differential between itself and Saudi Arabia by capitalising on the unprecedented regional upheaval of the Arab Spring to back the efforts of a whole array of dissidents then engaged in overthrowing the existing order. This placed Qatar increasingly at odds with the UAE, now widely viewed as Saudi Arabia's key security partner in upholding the regional status quo. ${ }^{3}$

Although their smallness may suggest that current enmities are temporary and that, before too long, Doha and Abu Dhabi will be compelled for structural reasons to return to traditional small state policies, manage their differences and resume cooperation on issues of mutual benefit, we suspect otherwise. We thus begin this paper by discussing the literature on small states, highlighting the theoretical challenges posed by the Emirati and Qatari cases. We argue that both approaches to foreign policy, though different in focus and execution, share an important characteristic all too rare among small states: a willingness to choose long-term strategic positioning over short-term stability.

As we show in the body of the article, diverging ideational and strategic considerations, in the cause of overcoming smallness, explain the ultimately colliding foreign policy trajectories of Qatar and the UAE. While both continue to regard Iran and Saudi Arabia as major latent threats, their contrasting outlooks on how best to secure future autonomy have their roots in how the ruling bargain has evolved since independence, and how ruling elites perceive themselves and their country's place in the wider region. Finally, we conclude by examining what the current breach between the UAE and Qatar tells us about the limits of such small state strategic ambition at the regional level.

\section{Overcoming smallness}

When Qatar and the UAE gained sovereign statehood at the beginning of the 1970s, they were some of the smallest 'micro-states' in the international system. Between them they could only claim a combined population of under one million and no cities of any regional significance. This raised concerns over whether such small actors

\footnotetext{
${ }^{2}$ On the growing alignment between Saudi Arabia and the UAE see Mason, R. (2018) Breaking the mould of small state classification? The broadening influence of United Arab Emirates foreign policy through effective military and bandwagoning strategies. Canadian Foreign Policy Journal, 24(1): 95-112.

3 Ibish, H. (2017) The UAE's Evolving Security Strategy The Arab Gulf States Institute in Washington, 6 April, http://www.agsiw.org/wp-content/uploads/2017/04/UAE-Security_ONLINE.pdf. Accessed 26 March 2018. For a comparative analysis of the UAE and Qatar, with a particular focus on their attitudes to, and relations with, the Muslim Brotherhood, see Roberts, D.B. (2017) Qatar and the UAE: exploring divergent responses to the Arab Spring. The Middle East Journal 71(4): 544-562.
} 
could even be classified as sovereign states in the eyes of international law, and whether they were able to fulfil the obligations of UN membership. ${ }^{4}$

These views were reflected in the literature on small states that emerged during the late 1960s in the shadow of rapid decolonisation and at the height of the Cold War between the Soviet Union and the USA. This scholarship was deeply influenced by the hard power realities of the bipolar world in which smallness and weakness were regarded as almost coterminous; following Kenneth Waltz, who emphasised the nature of the international system as structuring all inter-state behaviour, such third image approaches called attention to the preoccupation of the weak with fending off aggression by stronger states: 'Weak states operate on narrow margins. Inopportune acts, flawed policies, and mistimed moves may have fatal results'. This allows small states, who are assumed to be weak, little discretion in their foreign policy; external legitimation is the priority for such feeble actors, regardless of the ideological disposition of the incumbent government. ${ }^{6}$ They are compelled to resort to bandwagoning tactics or to seek safety in alliances. It is only when the nature of the international system changes, from bipolarity to a balance of power, for example, that such peripheral states have meaningful policy options. ${ }^{7}$ They do what they can to stave off intervention, and their foreign relations are ultimately a residual function of Great Power jockeying which itself is conditioned by the structure of the international system. ${ }^{8}$

Small states are therefore far more sensitive than larger powers to changes in the external environment because they lack, as Jervis argued, a 'margin of time and error', ${ }^{9}$ as well as the physical capabilities to respond effectively to external exigencies. ${ }^{10}$ This predicament spawns a foreign policy identity transfixed by those constraints; as Vital put it, 'Weakness [is the] most common, natural and pervasive view of self in the small state'. ${ }^{11}$ This understanding of their own vulnerabilities, and especially their limited capacity to move beyond foreign engagement that is both reactive and involuntary, forces small states to acknowledge that they "never, acting alone or in a small group, make a significant impact on the system'. ${ }^{12}$

\footnotetext{
${ }^{4}$ Mendelson, M.H. (1972) Diminutive states in the United Nations. International and Comparative Law Quarterly 21(4): 609-630.

5 Waltz, K.N. (1979) Theory of international politics Reading: Addison-Wesley Publishing Company, 195.

${ }^{6}$ Mastanduno, M., Lake, D.A. and Ikenberry, G.J. (1989) Toward a realist theory of state action. International Studies Quarterly 33(4): 457-474.

7 Handel, M.I. (1990) Weak states in the international system London: Frank Cass, 2nd ed.

8 Snyder, J. (1991) Myth of Empire: domestic politics and international ambition. Ithaca: Cornell University Press.

9 Jervis, R. (1978) Cooperation under the security dilemma. World Politics, 30(2): 172.

10 Wiberg, H. (1987) The security of small nations: challenges and defences. Journal of Peace Research, 24(4): 339.

11 Vital, D. (1967) The inequality of small states New York: Oxford University Press, 33.

12 Keohane, R. (1969) Lilliputians' dilemmas: small states in international politics. International Organization, 23(2): 295; Rothstein, R.L. (1968), Alliances and small powers New York, Columbia University Press: 34-6.
} 
Today, the great majority of the world's 200-plus legally sovereign states are small but productive members of the international community. This has profoundly changed earlier attitudes of policy-makers regarding the viability of smaller state actors and the positive contributions they might make to governance and security questions. ${ }^{13}$ What has not changed in both (neo-)Realist and post-internationalist scholarship is the view that the most striking characteristic, and consequence, of smallness in an anarchical context remains vulnerability. ${ }^{14}$ It is still widely accepted, for example, that size is an important variable in distinguishing differences in the foreign policy behaviour of states and that small states in the contemporary era will find it difficult to assert their own interests in external affairs. ${ }^{15}$

There is no question that the extent of participation of states in international affairs is largely dictated by the size of their surplus capabilities. In the early years after independence in 1971, the policies of Qatar and the UAE mirrored such considerations. At home, they prioritised, in typical small state fashion, institution building and economic development. Beyond their borders, they were preoccupied with fears of Iranian, Iraqi and Saudi attempts to annex their territory. Such anxieties, notably concerns over Ayatollah Khomeini's attempts to export Iran's Islamic Revolution, led Doha and Abu Dhabi to become founding members of the Gulf Cooperation Council in $1981 .^{16}$

Despite their growing populations, rapid domestic development, oil and gas wealth and high levels of military spending, the Emirates and Qatar remain small states when measured by traditional indicators. Respectively, the UAE and Qatar are ranked 92nd and 142nd on the UN's list of the world's most populous countries and 115 th and 164th in terms of territory. To put that into perspective: Qatar is smaller than Vanuatu in size and Jamaica in population, whereas the UAE has a territory equal to that of Austria and a population the same as Honduras. In terms of military power rankings that take into account available manpower, qualitative and quantitative capabilities as well as spending, the UAE lists 65th in the world compared to Qatar's near-bottom position at 100 (out of 136). ${ }^{17}$

\footnotetext{
13 Archer, C., Bailes, A. and Wivel, A. (2014) Small states and international security: Europe and beyond London: Routledge.

14 Desch, M.C. (1996) War and strong states, peace and weak states? International Organization 50(2): 237-268; Rosenau, J.N. (1990) Turbulence in world politics: A theory of change and continuity Princeton: Princeton University Press; Mearsheimer, J.J. (2001) The tragedy of great power politics New York: WW Norton \& Company.

15 Payne, A. (2004) Small states in the global politics of development. The Round Table: The Commonwealth Journal of International Affairs, 93: 623-635.

16 This concern was not hypothetical: for instance, Iran seized the three islands of Abu Musa and the Greater and Lesser Tunbs in 1971 from the UAE. On the historical three-way relationship: Kechichian, J.A. (ed.) (2001) Iran, Iraq and the Arab Gulf States New York: Palgrave.

17 World Population Prospects. (2017) The 2017 Revision: Key Findings and Advance Tables', UN Department of Economic and Social Affairs Population Division, New York, https://www.compassion .com/multimedia/world-population-prospects.pdf. Accessed 6 Jan 2018; IMF World Economic and Financial Surveys, World Economic Outlook Database, October 2017, https://www.imf.org/external/ pubs/ft/weo/2017/02/weodata/index.aspx. 19 February 2018; See '2018 Military Strength Rankings', https://www.globalfirepower.com/countries-listing.asp. Accessed 1 March 2018
} 
In line with this, since the start of the Gulf crisis in June 2017, both Abu Dhabi and Doha have shown themselves to be far more sensitive to changes in the external environment than the regional powers embroiled in the conflict. Qatar's forging of security relations with Turkey and, to a lesser extent, Iran to balance the threat posed by Saudi Arabia and the UAE and to reinforce its economic and political sovereignty was a classic small state response to vulnerability. And yet, throughout the crisis, both the UAE and Qatar have above all championed autonomous foreign policies that challenge some of the fundamental tenets in the traditional small state literature. Qatar's pro-active diplomatic engagement with Washington, Moscow and a host of important external actors across Europe, Africa and Asia since the start of the hostilities is testament to that. So is Abu Dhabi's refusal to slavishly embrace Riyadh's approach to vital issues, such as engagement with the forlorn Qatari opposition, when it contradicts its own preferences.

In doing so, the UAE and Qatar have demonstrated their refusal to accept the limitations of their 'smallness', reminding us of Henrikson's reflection that 'a small state's perception of its size is very subjective and differs greatly from the perception of other external parties'. ${ }^{18}$ By developing foreign policies that bypass conventional restrictions on their action radius, they have had a considerable impact on the regional system and beyond, demonstrating that there is not necessarily a consistent correlation between traditional size-based indicators of power and the capacity of small states to act outside their borders.

\section{State formation and foreign policy}

This combination of ability and willingness to overcome some essential constraints that standard accounts predict for states operating in the shadow of global and regional powers demands a historicisation of the foreign policy trajectories of the UAE and Qatar. Analysing them must begin with Ayoob's poignant observation that state-making remains at the heart of most non-Western states' international behaviour and that their external relations are, to a large extent, a function of domestic attempts at order creation; the state, in other words, cannot just be taken for granted as the basic unit of international relations, but must first consolidate its authority and position, internally and externally. ${ }^{19}$

'The politics of state survival', in Clapham's classic phrase, ${ }^{20}$ are not merely a matter of fending off external challenges (in Africa, the Middle East or elsewhere), but also of building both the hard, material institutions and practices of statehood, as well as narratives that legitimise the pre-eminence of certain forms of political

\footnotetext{
18 Henrikson, A.H. (2001) 'A coming 'Magnesian age? Small states, the global system, and the international community. Geopolitics, 6 (2001), 62-63.

19 Ayoob, M. (1998) Subaltern realism: international relations theory meets the third world. In: Neumann S. (ed.), International relations theory and the third world. New York: St Martin's Press, pp. 31-54.

${ }^{20}$ Clapham, C. (1996) Africa and the international system: the politics of state survival Cambridge: Cambridge University Press.
} 
authority and powerholders over others. Processes of building up empirical statehood and foreign policy development thus happen in parallel and constantly intertwine. Global pressures, international norms and regional rivalries all mould such trajectories, but so do domestic power struggles, (self-)perceptions and historically contingent identities. It is therefore important to underscore that Qatar and the Emirates are still relatively new players in the international system, where processes of state formation are ongoing and shape (and are shaped by) intra-elite competition. Because independent statehood was an imperial bequest rather than a drawn-out struggle for sovereignty, a national project-including potential federations, irredentisms and border disputes - and a concomitant cohesive set of national interests were still to be formulated.

In 1971, 3 years after Harold Wilson's Labour government announced its retrenchment 'East of Suez', Britain ended its long-time role as security provider for the Gulf sheikdoms including Qatar, Abu Dhabi, Dubai and the other Trucial States. In response, Abu Dhabi's Sheikh Zayed bin Sultan Al-Nahyan and Dubai's Sheikh Rashid bin Saeed Al-Maktoum agreed to establish the UAE. As a former Trucial State, Qatar was invited to join as a founding member of the federation but declined, highlighting from the earliest days of statehood its preference for positioning itself as resolutely distinct from other Gulf states. Over the next few years, five smaller Emirates-Sharjah, Ajman, Ras al-Khaimah, Fujairah and Umm al-Quwain-did join the UAE. This 'collection of leftovers', ${ }^{21}$ as one observer unkindly described them, looked at Abu Dhabi and Dubai for leadership.

Federation had a dual role: to provide enough cohesion to keep Iran, Saudi Arabia and Pan-Arabist meddlers at bay, while safeguarding the distinct traditions of the seven emirates, each with their own ruling families and political bases, and all at different stages of development. In practice, this complex state of affairs resulted in the erstwhile federation evolving along confederate lines as each emirate attempted to retain maximum autonomy, including separate armed forces and control over their own resources. This raised all sorts of anomalies and explains why the UAE is the only state in the world where offshore oil rights belong to the individual members of the federation rather than the federation itself.

In the early years, Abu Dhabi, which accounted for around $10 \%$ of the world's proven oil reserves, claimed most of the federation's territory, military power and wealth. Nevertheless, it still faced a difficult challenge in addressing the 'unity in fragmentation' that defined the UAE on the federal level. ${ }^{22}$ This required that Sheikh Zayed, Abu Dhabi's ruler and the first UAE president, skilfully balance the centrifugal tendencies and parallel economic and foreign policies of Dubai, Sharjah and the other Emirates amidst threats to their combined sovereignty. ${ }^{23}$

\footnotetext{
${ }^{21}$ Khalifa, A.M. (1979) The United Arab Emirates: unity in fragmentation Boulder: Westview Press, 141.

22 Ibid.

23 Zahlan, R.S. (1978) The origins of the United Arab Emirates: a political and social history of the Trucial States London: Macmillan. For a 21st century analysis of the UAE's rise: Ulrichsen, K.C. (2017) The United Arab Emirates: power, politics and policy-making London: Routledge.
} 
The Al-Thani family, which had dominated the Qatari peninsula since the nineteenth century, had different concerns. Domestic power struggles both before and after statehood were intra-familial rivalries that resulted in non-violent but involuntary regime change in 1949, 1960, 1972 and, most crucially, 1995. Otherwise, Qatar was remarkably stable as it focused, like the Emirates, on institutional and economic development from a very low base. ${ }^{24}$

Like the UAE, post-independence Qatar also had to deal with the hegemonic aspirations of its Saudi neighbour. ${ }^{25}$ In a region where religious identities and hierarchies have long been a source of power and legitimacy, Doha's subordination to Riyadh was underscored by the fact that it practiced the same brand of Wahhabi Islam. The upshot was that in its first two decades after independence Qatar generally deferred to the Saudi claim to leadership of the Sunni Gulf. It was, for example, one of the few Arab countries to observe the full forty-day mourning period after the assassination of Saudi Arabia's King Faisal in 1975 and the death of King Khalid in 1982.

Roberts has rightly noted the 'decisive role' of individual Qatari and Emirati leaders 'in shaping and reshaping state policy'. ${ }^{26}$ This was particularly evident when Hamad bin Khalifa became de facto ruler of Qatar in 1992. As heir apparent and minister of defence since the late 1970s, he had refused to acquiesce in a long-running border dispute with Saudi Arabia over Abu al-Khafous that was complicated when the UAE agreed, under pressure from Riyadh, to concede territory adjacent to Qatar in 1974. Tensions came to a head following Iraq's invasion of Kuwait in 1990, when Qatar denied Saudi requests for access to its territory, instead setting up the Khafous border post to monitor Saudi deployments. In 1992, clashes over border demarcations resulted in two deaths. Animosity continued in 1993 and 1994, when Qatar boycotted the GCC summit conference. Fearing the growing autonomous thrust of Hamad, Saudi Arabia, Bahrain and the UAE sided against him in the summer of 1995 after he deposed his own father in a bloodless coup with the backing of most of the ruling family. The (ineffective) meddling of his Gulf neighbours further affirmed the new sovereign's evolving strategic vision to shape a 'global' Qatar suited to the twenty-first century.

\footnotetext{
${ }^{24}$ Zahlan, R.S. (1979) The creation of Qatar London: Croom Helm; al Mallakh, R. (1979) Qatar: Development of an Oil Economy New York, St. Martin's Press; al-Shalaq, A.Z. (1999) Fusul min Tarikh Qatar al-Siyasi [Chapters from Qatar's Political History] Doha: A.Z. al-Shalaq. For a more recent assessment: Roberts D.B. (2017) Qatar: Securing the Global Ambitions of a City-State London: Hurst.

25 For two insightful analyses of the security threats faced by the Gulf states in this period see Al-Alkim, H.H. (1994) The GCC States in an Unstable World: Foreign Policy Dilemmas of Small States London: Saqi Books and Cordesman, A.H. (1997) Bahrain, Qatar, Oman and the UAE: challenges of security Boulder: Westview Press.

26 Roberts, Qatar and the UAE: exploring divergent responses to the Arab Spring, 559.
}

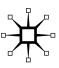




\section{The Al Jazeera effect}

On his first trip to Washington as Emir, in 1997, Sheikh Hamad stressed that greater openness was necessary to 'secure ourselves in the future'. ${ }^{27}$ In line with this coupling of national security, state autonomy and a new external orientation, he emphasised a Qatari identity clearly distinct domestically and internationally from its Gulf neighbours. We term this strategy 'the Al Jazeera Effect', since the Qatari news network that reinvented reporting in the Arab world best embodies Doha's multifaceted attempts to escape from its historically peripheral role in Gulf and wider Muslim World politics.

In the absence of a military capability, among other traditional hard power instruments, the new emir invested heavily in Al Jazeera's ability to reach record audiences and be different. Supported by journalists and technicians from across North Africa, the Levant and the Horn, this move was intended to 'put tiny Qatar on the map', ${ }^{28}$ as Hamad explained on the network's launch in 1996. Just as Gamal Abdel Nasser instrumentalised the Sawt al-Arab radio station to export his Pan-Arabism and give Egyptian diplomacy unprecedented reach in the $1950 \mathrm{~s}$ and $1960 \mathrm{~s}^{29}$, so Al Jazeera would soon revolutionise foreign policy engagement, as well as the media landscape, in the twenty-first-century wider Middle East. ${ }^{30}$

Thus, the Al Jazeera effect encompasses much more than the broadcaster's global activities. Hamad also funded the development of a western-oriented educational sector on a scale unmatched anywhere in the Middle East. One of his earliest initiatives was to establish the Qatar Foundation and to build Education City on the outskirts of Doha, where the Foundation is housed alongside six branch campuses of prestigious research institutions including Georgetown, Northwestern and Cornell, the largest enclave of American universities overseas. Apart from promoting liberal tertiary education, his government also backed the development of heterodox Islamic curricula and, driven forward by his wife Sheikha Moza bint Nasser, current chairperson of the Qatar Foundation, carved out a place for women at the heart of government and wider civil society.

Furthermore, Qatar began hosting a whole gamut of dissidents from across the Muslim World who became valuable intermediaries to Doha's wider ambitions. With one eye on the conservative instincts of important swathes of Qatari society, the ruling family does not see a contradiction in simultaneously embracing a hypercosmopolitan liberalism and providing a refuge for a variety of figures associated with the Muslim Brotherhood and other Islamist groups. These have included senior

\footnotetext{
27 Douglas Jehl, 'Young Turk of the gulf: emir of Qatar', the. New York Times, 7 July 1997, https://www. nytimes.com/1997/07/10/world/young-turk-of-the-gulf-emir-of-qatar.html

28 Wildermuth, N. (2005) 'Defining the "Al Jazeera effect": American public diplomacy at a crossroad. Media Res, 1(2).

29 Brennan J. (2010) Radio Cairo and the Decolonization of East Africa, 1953-1964. In Lee C. (ed.) Making a World After Empire. The Bandung Moment and its Political Afterlives. Athens: Ohio University Press: 173-195.

${ }^{30}$ Gilboa, E., Powers, S. (2007) The public diplomacy of Al Jazeera in P. Seib (ed.), New media and the new Middle East New York: Palgrave Macmillan, pp. 53-80.
} 
members of the anti-Assad opposition and leaders of Hamas, the Palestinian branch of the movement. In 2012, after the group closed its Damascus office, the head of Hamas' political bureau, Khaled Meshaal, moved his operation to Doha.

Thus, from the start of his reign, Hamad initiated an unprecedented and multidimensional foreign policy, resolutely pragmatic in character but profoundly threatening from the perspective of Saudi Arabia. In part, Doha was able to encourage liberalism and Islamism on Riyadh's doorstep and to report critically, via Al Jazeera, on the Saudi elite by exploiting unprecedented strains in the post-9/11 US-Saudi relationship. Building on its status as home to a major US airbase and one of the largest overseas American military pre-positioning facilities, by the start of the Iraq war in 2003, Qatar had established itself as the successor to Riyadh as Washington's command centre for air operations in Afghanistan and Iraq.

The nimble casting of Qatar as an alternative model of society, as well as a vital American ally, contrasted starkly with Saudi Arabia's plummeting international reputation. ${ }^{31}$ This provided Doha with security shelter under Washington's defence umbrella, offering explicit protection from Tehran and a subtle check on Riyadh. It also provided the context for Sheikh Hamad's regional diplomatic offensive that, until his abdication in favour of his son Tamim in 2013, challenged the traditional view that small states are reactive and weak entities incapable of developing an independent foreign policy and of little importance in international affairs.

Kamrava introduced the concept of 'subtle' power to differentiate Qatar's attempt to influence events beyond its borders from the soft power elucidated by Joseph Nye and others. ${ }^{32}$ One crucial instrument in this became conflict mediation, with Doha positioning itself as the Oslo, Geneva or Vienna of the Islamic World: a destination for belligerents' intent on undertaking discreet, if not secret, talks. Although its experience brokering peace in Sudan's war-torn Darfur region has been haphazard and controversial, Qatar can claim some limited successes in this role. ${ }^{33}$ In 2008 , it brought together all opposing Lebanese factions, including the pro-Iranian Hezbollah, and helped avert civil war. In 2009, it took the lead role in mediating the breakdown in relations between Hamas and the Fatah-led Palestinian Authority.

Yet the actual outcome of such talks was not always their most important consequence. Common to all these engagements is an apparent need on the part of Qatar's rulers to provide regular reminders, to its own people and foreign friends and enemies, of its independence. In the process, it has been willing to anger much bigger and more powerful actors, especially Saudi Arabia, and in the case of Lebanon and Israel-Palestine, Egypt and the USA as well.

This constant quest for leverage vis-à-vis bigger regional actors and the desire to play a role that its mere size would seem to preclude also led Qatar to forge deep

\footnotetext{
31 Ottaway, D. (2009) The King and US: US-Saudi relations in the wake of 9/11. Foreign Affairs, 88(3): 121-131.

32 Kamrava, M. (2013) Qatar: Small state, big politics. Ithaca: Cornell University Press.

33 Barakat, S. (2014). Qatari mediation: between ambition and achievement. Brookings Doha Center, Analysis Paper Nov, https://www.brookings.edu/research/qatari-mediation-between-ambition-and-achie vement/. Accessed 25 March 2018.
} 
links with an assortment of iconoclastic Islamists, including the Taliban in Afghanistan, the jihadist resistance in Syria and Libya and, as noted above, Hamas in Gaza and different branches of the Muslim Brotherhood in Tunisia, Turkey, Sudan and Egypt. In the latter case, following the overthrow of the Mubarak regime in early 2011, Saudi Arabia and the UAE championed a return to the status quo. ${ }^{34}$ Doha backed something much more novel and unpredictable. As Hamad Bin Jassim AlThani, Qatar's prime minister, argued in 2011, the Islamists of the Brotherhood should be 'tried' to see if they could make a positive contribution to the region. ${ }^{35}$

Such dallying with Islamist groups-from keeping communication lines open to providing extensive financial and political assistance-has led to accusations that Doha is committed to radical ideological goals, at odds with the national security objectives of its partners in the Gulf and the West. ${ }^{36}$ What such characterisations underestimate is the extent to which Qatar, in its attempt to overcome the constraints of geography and anarchy, has embraced a deeply pragmatic rather than ideological foreign policy approach.

This has been amply demonstrated in its dealings with Israel over the last two decades. In May 1996, the same month as the right-wing Likud leader Benjamin Netanyahu became prime minister, Qatar allowed Israel to open a trade representation office in Doha, making it the first GCC state to grant de facto recognition to Israel by launching trade relations. ${ }^{37}$ The following year it invited Israel to attend the MENA economic summit in Doha. Despite pressure from Arab partners who boycotted the event in protest at the stalled Oslo peace process, Qatar refused to cancel the meeting, insisting that it had the sovereign right to chart its own foreign policy. Fast forward to March 2018, and despite a significant worsening in bilateral Qatari-Israeli relations since the collapse of Oslo, Doha continues to pragmatically work with Israel in providing humanitarian aid to Gaza. Tzachi Hanegbi, Israel's minister for regional cooperation, recently praised Qatari officials for working closely with the Israeli authorities and acknowledged that Doha was 'endeavoring hugely to ensure its aid [to Gaza] .... does not end up as any Hamas force build-up'. 38

What unites these apparently contradictory choices-domestic liberalism alongside an open-door policy for Islamists; external support for conservative/reactionary movements while openly engaging with Israel in defiance of many Arab partners; not to mention proudly hosting two of America's largest and most strategically

\footnotetext{
${ }^{34}$ Lynch, M. (2013) Money to meddle: can the wealthy powerbrokers of the Persian Gulf create the Egypt they want? Foreign Policy, 11 July http://foreignpolicy.com/2013/07/11/money-to-meddle/. Accessed 1 Feb 2018

35 Cited in Miller, R. (2016) Desert kingdoms to global powers: the rise of the Arab gulf New Haven: Yale University Press, p. 249.

36 Dickinson, E. (2014) The case against Qatar. Foreign Policy, 30 Sept. http://foreignpolicy. com/2014/09/30/the-case-against-qatar/. Accessed 1 Feb 2018.

37 Rabi, U. (2009) Qatar's relations with Israel: challenging Arab and Gulf norms. Middle East Journal 63(3): 443-59.

38 The Times of Israel. (2018) Israeli minister: Qatar making true effort to stop Gaza aid from boosting Hamas, 16 March, https://www.timesofisrael.com/israeli-minister-qatar-making-true-effort-to-stop-gazaaid-from-boosting-hamas/. Accessed 5 Apr 2018.
} 
placed overseas bases that play a key role in the air war against Islamic State in Syria and Iraq - is not only Qatar's desire to distinguish itself from its neighbours as a matter of national identity. Nor is it simply a determination to resist outside attempts to dictate its policies. Rather, this pragmatism, in contrast to the ideologically driven approaches of Saudi Arabia and Iran, has served as Qatar's most important instrument in consolidating its strategic usefulness.

Qatari willingness to quite literally talk to everybody has seen it branded over the years as a rudderless, ${ }^{39}$ political maverick 'with no politics'. ${ }^{40}$ But this is exactly what has enabled it to develop into an invaluable intermediary. It was a crucial factor, for example, in the negotiation of the release of U.S. Sergeant Bowe Bergdahl from Taliban captivity in 2014. It was instrumental in delivering the freedom of Italian hostages held in Syria by anti-Iranian Al-Qaeda affiliate Jabha al-Nusra the following year and in gaining the release of 26 of its own citizens in 2017, held in captivity for 16 months by pro-Iranian Shi'a militias in Iraq. It is this unique profile of ideological flexibility and a distinct domestic and foreign policy identity, backed by a hydrocarbon powered 'Riyal Politik', ${ }^{41}$ that has empowered Doha to influence struggles for (geo)political power in North Africa (Libya, Egypt), the Horn (Somalia, Sudan) and the Levant (Lebanon, Palestine, Syria).

The Al Jazeera effect has enabled Qatar to exert a regional influence that greatly exceeds what one would expect for a typical (or even atypical) small state. Its flagship media creation embodies both its identity and its achievements. While the network has generated plenty of controversy and accusations of overreach that reverberate during the present crisis, its overall success in accomplishing Sheikh Hamad's stated objectives cannot be denied.

One reason for this is the unmistakeably populist and iconoclastic editorial line of Al Jazeera Arabic's reportage embodied in its slogan, 'the opinion-the other opinion'. ${ }^{42}$ This attracted a huge audience, 35 million in its first 2 years alone. Hamad, who had abolished the ministry of information on the eve of launching Al Jazeera, explained that the 'TV station [was] reflecting the new image of Qatar'43 and the spillover from the network's success and global brand recognition, especially after the launch of Al Jazeera English in 2006, quickly came to define Qatar's status as a visionary Arab actor.

As its popularity and influence soared, so did the threat it posed to the status quo. By the mid-2000s, almost every government in the Arab world had lodged a formal

\footnotetext{
39 Khatib, L. (2013) Qatar's foreign policy: the limits of pragmatism. International Affairs, 89(2): 417431.

${ }^{40}$ Cook, S.A. (2004) A country with no politics. The Weekly Standard, 22 Nov. https://www.weeklystan dard.com/steven-a-cook/a-country-with-no-politics. Accessed 16 March 2018.

41 Baaboud, A. (2005) Dynamics and determinants of the GCC States' foreign policy, with special reference to the EU. In: Nonneman, G. (ed.), Analysing Middle East Foreign Policies and the Relationship with Europe. London: Routledge, pp. 145-173.

42 Lynch, M. (2006) Voices of the new Arab public: Iraq, Al Jazeera, and Middle East politics today. New York: Columbia University Press.

43 Bahry, L.Y. (2001) The new Arab media phenomenon: Qatar's Al Jazeera. Middle East Policy 8(2): 88-99.
} 
complaint with Doha over the network's critical reporting, summarily closed down local Al Jazeera offices, or refused correspondents entry into their countries. Qatar's GCC partners were outright hostile. Bahrain banned the channel. Policy-makers in Oman, Kuwait and the UAE warned western officials that Al Jazeera was inciting hatred and destabilising the entire region and urged them to use their influence over Qatari leadership to reign in the channel. An indignant Saudi leadership was furious over Al Jazeera's willingness to provide a platform for the kingdom's legion of dissidents. In front of an audience of millions, they accused the Saudi royal family of corruption, human rights abuses and incompetence. In response, in 2002 Riyadh broke diplomatic relations with Doha and for the next 6 years until bilateral ties were restored, laboured to discredit Al Jazeera at every opportunity, even establishing its own news channel, Al Arabiya, to provide a counter-narrative. ${ }^{44}$

As Baehr has shown, small states tend to be limited in regard to the "quantity and diversity' of information that they can disseminate. ${ }^{45}$ Yet Al Jazeera's importance as an instrument to promote Qatar's interests and expand its autonomy through the control of information culminated at the start of the Arab Spring when it led the way in covering the revolutions gripping Tunisia, Egypt and Libya in real time. In response, the besieged authorities in all three countries looked to silence the network, in the case of Egypt even shutting down the satellite that broadcast the channel. They also accused the Qatari government of using the network to incite popular protest and promote regime change. Though Doha denied this charge, there was no ignoring the soft power capabilities, embodied in Al Jazeera, that it now wielded on the regional level.

\section{The DP world vision}

The UAE has followed a different path to achieve its strategic objectives and escape the constraints of smallness. Fuelled by Abu Dhabi's oil wealth and Dubai's entrepreneurial spirit, UAE leaders initially looked to balance the Saudi threat not through geopolitical competition but through private sector growth that drove prosperity across the federation while pursuing a conservative foreign policy. The UAE became a high-income nation in 1987 by championing logistical and commercial infrastructure, including the establishment of the region's first and largest free zone, Jebel Ali, which offered foreign businesses $100 \%$ ownership, full repatriation of profits, and excellent services in a tax-free environment. By the early 2000s, the UAE was the Arab world's most globalised and third-largest economy behind Saudi Arabia and Egypt, with its per capita income far higher than that of these much larger countries. It also became the top investor in other Arab countries, including the number one foreign investor in Saudi Arabia.

\footnotetext{
44 Cherkaoui, T. (2014) Al Jazeera's changing editorial perspectives and the Saudi-Qatari relationship. The Political Economy of Communication, 2(1): 17-32.

45 Baehr, P.R. (1975) Small states: A tool for analysis. World Politics, 27(3), 462.
} 
Emboldened by this spectacular transformation, the UAE looked to overturn the traditional regional economic order by challenging Saudi leadership on issues ranging from free trade to the reconstruction of Iraq. The culminated in 2008 when the UAE and Saudi Arabia clashed over whether a prospective GCC Central Bank, known as the Gulf Monetary Council, should be located in Riyadh or Abu Dhabi. Unable to get Saudi leaders to agree to the UAE capital, Abu Dhabi announced that the Emirates would not participate in any future Gulf monetary union, a zero-sum move that ensured that future attempts to build a viable GCC-wide capital market or develop a unified regional trade policy would be still-born.

Yet the largely confederate structure hampered Abu Dhabi's attempts to transform its impressive economic clout into political influence. In part this was due to the different material interests, and social and cultural contexts ${ }^{46}$ that existed in the seven individual emirates, not least fiercely autonomous Dubai that realised a globally recognised 'miracle' in its own right. ${ }^{47}$ Remaining in the shadows of Saudi and Iranian pre-eminence, the UAE was left with little choice but to prioritise 'economic interests over political divisions and differences'. ${ }^{4}$

The global financial crisis changed that dramatically by enabling Abu Dhabi to dominate the federation at the expense of Dubai in a way that was unimaginable just a few years earlier. Between 2000 and 2008, Dubai's economy grew at 13\% annually on average, faster even than China and India over the same period. ${ }^{49}$ Yet, below the surface this trendsetting, no-limits emirate faced profound structural problems. Public debt stood at US\$147 billion, over $100 \%$ of GDP. The real estate market, responsible for attracting much of the overseas investment over the previous decade, was overextended. In this environment, the global credit crisis delivered an uppercut to Dubai World, the huge state-owned holding created by the ruling al-Maktoum family to run its business interests. Abu Dhabi, which sits on $94 \%$ of the federation's oil reserves, intervened with a multi-billion dollars rescue package. This manoeuvre redefined the power dynamic between the federation's two key players after decades during which Dubai had successfully narrowed the gap with its neighbour. ${ }^{50}$

Since then, power has been centralised in Abu Dhabi. Foreign and defence matters, as well as pivotal tenets of economic policy, are now firmly under the control of the UAE's strongman, Crown Prince Mohammed bin Zayed Al-Nahyan, who unlike his cautious father believes that the federation should develop a regional and global political role commensurate with its economic transformation. ${ }^{51}$

\footnotetext{
46 On the cultural factors influencing the evolving power inter-relationships between the seven emirates, see Rugh, A.B. (2007) The Political Culture of Leadership in the United Arab Emirates. New York: Palgrave Macmillan.

47 Molavi, A. (2005) Dubai rising. The Brown Journal of World Affairs, XII(1): 103-110.

48 Al-Mashat, A.M. (2008) Politics of constructive engagement: the foreign policy of the United Arab Emirates. In Korany, B. and Dessouki, A.H. (eds.) The foreign policies of Arab states: the challenge of globalisation Cairo: American University of Cairo Press, 464.

49 Winckler, O. (2010) Can the GCC weather the economic meltdown? Middle East Quarterly, 17(3)

50 See Davidson, C.M. (2007) The Emirates of Abu Dhabi and Dubai: Contrasting Roles in the International System Asian Affairs, 38(1): 33-48.

51 Pinto, V.C. (2014) From "Follower" to "Role Model": the Transformation of the UAE's International Self-Image Journal of Arabian Studies, 4(2): 231-243.
} 
Abu Dhabi's new mastery of decision-making and its evolution from a 'consumer' into a 'contributor' to regional security structures ${ }^{52}$ has not entailed a marginalisation of Dubai's importance to the global UAE brand. Rather, the vision that Mohammed bin Zayed is pursuing synthesises the perceived strengths of the federation's leading emirates; he has elevated the Dubai dream-being the commercial and financial hub connecting East and West ${ }^{53}$-into the aspiration of the UAE as a whole: to become the dominant geo-economic force in the Western Indian Ocean World, making it an indispensable mercantile, financial and political partner to superpowers and small states alike in a region stretching from the ports of the Indian Subcontinent to the bustling cities of the Arabian Peninsula to the growing markets of Africa's Eastern flank down to the Cape.

According to such thinking, the UAE will develop into the ultimate 'nexus state', a metronome for global trade that connects producers and consumers across the Middle East, Africa and Asia with each other and with the rest of the planet. ${ }^{54}$ The key instrument is Dubai Ports World-DP World for short-the state-owned maritime logistics juggernaut which owns more than 75 terminals on all six continents and which has seen its revenues increase by more than $50 \%$ in the last 5 years. DP World operates specialist vessels, offers stevedore services and operates cargo rail connections but above all manages ports, particularly in the Indian Ocean which it sees as crucial to both the future of the world economy and the UAE's regional aspirations. Jebel Ali is the busiest container port in the world outside East Asia and is indispensable to all forms of commerce in and between the Middle East, East Africa and the Indian Subcontinent. ${ }^{55}$ Moreover, on completion, Dubai World Central, a multi-modal logistics base, will be twice as large as Hong Kong Island and will move $12 \mathrm{~m}$ tons of freight annually.

Jebel Ali sits at the centre of a web of DP World terminals across South Asia, South-East Asia and Australia, where it has half a dozen facilities in each. DP World has also rapidly acquired ports in Djibouti, Eritrea, Somaliland and Somalia. The fact that so many facilities in the Western Indian Ocean especially (Aden, Assab, Berbera) have dual use capabilities and are allowing the UAE to have a naval and air force presence alongside its commercial interests displeases land-locked regional powers like Ethiopia which fear near-total Emirati dominance of import and export routes, underpinned by military support for its historical enemies in Eritrea and Somalia. ${ }^{56}$ Recent changes in Ethiopia's political leadership with the rise of Premier

\footnotetext{
52 Ulrichsen, K.C. (2017) Transformations in UAE foreign policy Al Jazeera Centre for Studies June http://studies.aljazeera.net/en/reports/2017/06/transformations-uae-foreign-policy-170608095838131 .html. Accessed 7 March 2018. On the evolution of this shift see also Davidson, C.M. (2005) The United Arab Emirates: a study in survival Boulder, Lynne Rienner.

53 Akhavan, M. (2017) Development dynamics of port-cities interface in the Arab Middle Eastern worldThe case of Dubai global hub port-city. Cities 60: 343-352.

54 Henderson, C. (2017) The UAE as a nexus state. Journal of Arabian Studies 7(1): 83-93.

55 Ziadah, R. (2018) 'Transport infrastructure and logistics in the making of Dubai Inc. International Journal of Urban and Regional Research, 42(2): 182-197.

56 Verhoeven, H. (2018) The Gulf and the Horn: changing geographies of security interdependence and competing visions of regional order. Civil Wars 20(3): 333-357.
} 
Abiy Ahmed have allowed Addis and Abu Dhabi to reset relations and attempt pragmatic cooperation, but the assertive-cum-aggressive Emirati geo-economic push remains a difficult proposition in the Horn of Africa. ${ }^{57}$

The DP World vision explains why the UAE has been the most active Gulf player in anti-piracy operations in the Indian Ocean, as well as the most persistent intervener in Somali domestic politics. It also illuminates its involvement in the Yemen war. There is no question that the Emirati alliance with Saudi Arabia in countering the Houthis is informed by fears over Iranian encroachment on the Arabian Peninsula. Yet this military engagement must also be understood as part of the UAE's broader thrust to occupy pivotal positions all around the Red Sea and the Western Indian Ocean. ${ }^{58}$

This strategy also underpins Abu Dhabi's resolute support for Sisi's Egypt, its deployment of warships between Arabia and Africa and its use of Eritrean territory to launch airstrikes on Yemen. Intent on countering the threat posed by Abu Dhabi's two arch-enemies-revolutionary Iran and the Muslim Brotherhood-the UAE has also seized the Yemeni island of Socotra and developed intimate commercial, political and military ties with elites all along the seashores, giving it vital influence from Libya in the Mediterranean across the Red Sea to the Arabian Sea and the coasts of East Africa.

The innovative synergy of maritime-mercantile power sets the UAE apart from its rivals. Fuelled by the unbridled ambition and wealth of Abu Dhabi's leaders, these expansive (and expensive) designs are inseparable from Dubai's core article of faith-that commerce can serve as a vehicle for economic diversification out of oil and as a lever of power on the global stage. DP World's success in implementing this vision, with the backing of globally renowned sovereign wealth funds and a state-of-the-art navy, equips the Emirates with a strategic asset that none of its regional competitors possesses.

\section{Stress testing strategy}

The rise of the UAE and Qatar over the last 15 years is clearly more than just a function of their incredible resources endowment. Congo, Libya and Venezuela are among the great many state extractors of hydrocarbons, gold, diamonds and other strategic commodities, falling victim to the dreaded 'resource curse'. ${ }^{59}$ Few of those that have avoided institutional decay, protracted conflict and economic volatility, have followed Norway's example and become successful international peace and security entrepreneurs. The ability of Qatar and the UAE to do so is, in other words,

\footnotetext{
57 Woldemariam, M. (2019) The Eritrea-Ethiopia Thaw and its Regional Impact. Current History 118(5): 181-187.

58 Maclean, W., Browning, N. and Bayoumy, Y. (2016) Yemen Counter-Terrorism Mission Shows UAE Military Ambition. Reuters, 28 June. https://www.reuters.com/article/us-yemen-security-emirates/yemen -counter-terrorism-mission-shows-uae-military-ambition-idUSKCN0ZE1EA. Accessed 1 Feb 2018.

59 Ross, M.L. (1999) The Political economy of the resource curse. World Politics 51(2): 297-324
} 
not only a matter of resources but also of how those resources are deployed, and to what end: this is why we argue that the DP World vision and the Al Jazeera effect have been so consequential.

These respective stratagems to overcome smallness still contain major perils for what remain two small states. The current Gulf Crisis has painfully exposed some of the contradictions and vulnerabilities inherent in both. Qatar was transformed overnight from a pro-active international actor into a besieged small state in a hostile regional environment with little choice but to defend its core interests from the coalition ranged against it. Coming so soon after allies and partners in Egypt, Somalia, Syria and elsewhere had suffered considerable setbacks, the scale and timing of the breach suggested that Doha's policy of emphasising difference in the pursuit of autonomy had reached its limits. So too did Qatar's immediate response of prioritising, above all else, security ties with the two biggest military powers in the Middle East-first Turkey and then the USA. The conventional view in the literature is that a small state requires a powerful protector when challenged by larger neighbours; ${ }^{60}$ these moves appeared to confirm that Qatar was finally reverting to small-state type.

At the same time, in the first phase of the crisis, Qatar managed to contain the impact of the blockade and to maintain its political autonomy and economic sovereignty even without an explicit commitment to its security from the Trump administration. One reason for this was the skill with which it allocated the surplus financial resources generated by its gas revenues. These included the import of vital supplies, the development of new trade corridors, and continued access to international airspace by ensuring the normal functioning of Qatar Airways. Throughout the crisis, Qatar also demonstrated agility, including the smart use of bilateral economic ties, to persuade actors across Europe, Africa and Asia to remain neutral, which implicitly meant rebuking the Saudi-Emirati embargo. Furthermore, it negotiated the vital upgrade in bilateral security relations with Turkey and convinced Washington, in early 2018, to publicly reaffirm its security commitment to Qatar after an initial period when President Trump strongly sympathised with the actions of the UAE-Saudi coalition. Speaking in the wake of the first annual US-Qatari Strategic Dialogue, U.S. Secretary of Defence James Mattis acknowledged the importance of the Al-Udeid base to warfighting in Afghanistan and Iraq. Before the Senate Armed Services Committee, the head of CENTCOM, General Joseph Votel, expounded on the 'invaluable regional access through basing and freedom of movement' ${ }^{61}$ provided by Qatar over 20 years. Consistently aligning its foreign policy with Washington's regional defence agenda for the last two decades has proven its value for Qatar in helping it overcome structural limitations at a time of need.

Sheik Tamim's speech at the Munich Security Conference in February 2018 challenged the inhibitions of smallness. 'The failed blockade' showed 'how small states can use diplomacy and strategic economic planning to weather the storms of

\footnotetext{
60 Walt, S.M. (1987) Origins of alliances Ithaca: Cornell University Press, 25-29.

61 Statement of General Joseph 1. Votel, Commander US Central Command before the Senate Armed Services Committee on the posture of US Central Command. (2018) 13 March https://www.armed-servi ces.senate.gov/download/votel_03-13-18. Accessed 19 March 2018.
} 
aggression from larger, ambitious neighbours'. ${ }^{62}$ Even accounting for the glossing over of the financial cost to Qatar of its counter-embargo strategy, its success underscores how the country, despite its size, and even when under siege, has been able to consolidate its position as an effective diplomatic influencer. ${ }^{63}$ Its ability to maintain close ties with Washington and key European states like Germany and France has undermined the assumption underpinning UAE-Saudi actions that Qatar is a strategic liability to Western interests in a turbulent region. Simultaneously, it illuminates the failure of Abu Dhabi or Riyadh to offer a plausible alternative security architecture to replace the GCC framework that they jettisoned when they broke with Doha, in the process also frightening Oman and Kuwait. This weakens their claims to regional leadership and may ultimately reflect most poorly on Abu Dhabi's Mohammed bin Zayed, who many believe to be responsible for initially convincing Saudi Crown Prince Mohammed bin Salman of moving against Doha.

The embargo has also generated other kinds of blowback for Abu Dhabi. Relations between the UAE and Turkey have been tense since the Arab Spring, when Turkish leader Recep Tayyip Erdoğan backed the Muslim Brotherhood in Egypt and Tunisia. In 2013, the Emirati ambassador was recalled from Ankara and the UAE sided with Russia when one of its fighter jets was shot down over Turkish territory in late 2015. Prior to the current crisis, Abu Dhabi had managed to limit Turkish influence in the Gulf by holding in check the burgeoning relationship between Doha and Ankara through diplomatic pressure inside the GCC. The current crisis, ironically, has resulted in unprecedented trade and security cooperation between Qatar and Turkey.

Of even more concern is the extent that the embargo has contributed to the erosion of Jebel Ali's geo-commercial dominance. Qatar's re-routing of supply lines has been a boon to Oman, which has used the crisis to accelerate its efforts to position itself as a more geographically convenient (and less geopolitically ambitious) alternative to Dubai for the wider Indian Ocean. China especially, as part of its Belt and Road Initiative, has prioritised ties with Muscat and is pouring billions into the Duqm port, industrial city and free trade area to directly challenge DP World. ${ }^{64}$ Muscat's excellent understanding with Beijing, as well its unthreatening foreign policy along the Oceanic Rim, makes it a potentially more attractive long-term partner than the UAE for both China and African states. This is especially bad news given the breakdown in relations between the UAE and Somalia following the latter's refusal to drop Qatari patronage and Djibouti's decision in February 2018 to nationalise the formerly DP World controlled Doraleh facility. Emirati overstretch

\footnotetext{
62 Speech of Qatar emir at Munich security conference. (2018) reprinted in The Peninsula, 16 Feb., https ://thepeninsulaqatar.com/article/16/02/2018/Speech-of-Qatar-Emir-at-Munich-Security-Conference

63 For an informed analysis that makes this argument see Cole, J. (2018) David and Goliath: How Qatar Defeated the Saudi and UAE Annexation Plot The Nation, 16 Feb. https://www.thenation.com/article/ david-and-goliath-how-qatar-defeated-the-saudi-and-uae-annexation-plot/. Accessed 17 Feb 2018

64 Han, Z., Chen, X. (2018) Historical Exchanges and Future Cooperation Between China and Oman Under the "Belt \& Road" Initiative. International Relations and Diplomacy, 6(1), 1-15.
} 
and mishandling of ties with elites in Addis, Djibouti and Mogadishu might cost its flagship enterprise dearly. ${ }^{65}$

These considerable setbacks notwithstanding, the UAE's attempts to overcome smallness seem on track in other regards. Since the crisis began, a consensus has formed that credits Mohammed bin Zayed as the driving force in an anti-Qatar coalition that includes two major regional powers: Egypt and Saudi Arabia. Whether true or not, this bolsters the (self-)perception of the UAE as increasingly the key actor in inter-Arab security affairs. The current stand-off has also provided the UAE with the opportunity to position itself as an equal to Saudi Arabia in intra-Gulf affairs, as evidenced by the announcement in Abu Dhabi in December 2017 of the formation of a new UAE-Saudi two-member political and military alliance intended to marginalise the already moribund GCC. Strategic parity with Riyadh, long a distant Emirati dream, now appears to be within reach.

Linked to this, the crisis has in no way tempered the UAE's 'ambition to be at the forefront of military innovation', dixit CENTCOM. ${ }^{66}$ In February 2018, the Emirati armed forces gave their biggest ever public demonstration of hardware and live battle action scenarios. This was a celebration of military prowess, emphasising its central role in the US war on terror against Al-Qaeda in the Arabian Peninsula and ISIS. It also served as a reminder to observers across the wider region that the UAE retains both the capacity and willingness to act 'out of area' to assert its interests, as it did with bombing raids 5000 kilometres from home in Libya in 2014.

\section{Conclusion}

'Beware of small states', warned Mikhail Bakunin in a letter dated $1870 .{ }^{67}$ Although the Russian anarchist disliked all states, he considered peripheral ones that refused to comply with what (neo-)Realists perceive to be the core tenets of the international system as a particularly problematic source of geopolitical upheaval. This article has focused on the ways in which two such states, Qatar and the UAE, have (re)positioned themselves in the international system.

Situating their evolving foreign policy trajectories in ongoing processes of state consolidation and domestic and Gulf-wide elite rivalries, we highlighted how both Doha and Abu Dhabi have acted assertively to maximise their autonomy and reshape their environments, in the process undermining existing regional hierarchies. Rather than engaging in straightforward alliance building or bandwagoning based on threats to the balance of power from big regional states such as Iran, it is the perceived congruence with their visions to surmount smallness in a context of

\footnotetext{
65 For further background: Meester, J., van den Berg, W. and Verhoeven, H. (2018) Riyal Politik. The Political Economy of Gulf Investments in the Horn of Africa The Hague: Clingendael Institute.

66 Statement of General Joseph 1. Votel, Commander US Central Command before the Senate Armed Services Committee on the posture of US Central Command. (2018) 13 March https://www.armed-servi ces.senate.gov/download/votel_03-13-18. Accessed 19 March 2018.

${ }^{67}$ Cited in Hurst, D. (2010) Beware of small states. Lebanon, battleground of the Middle East London: Faber and Faber, p. 2.
} 
'ideological and power multipolarity in the Middle East' ${ }^{68}$ that shapes the identification of potential partners by Qatar and the Emirates. This upends conventional assumptions about small states as weak, reactive actors operating on the margins of international affairs. If the Emirati gamble is that a sophisticated ports network combined with Indian Ocean commerce will enable it to escape the constraints of smallness, Qatar's strategy to achieve the same end has been to promote itself as radically distinct from its Gulf neighbours, explicitly challenging much larger regional actors, notably Saudi Arabia.

This divergence in foreign policy is thus not merely the result of tactical jockeying since the start of the Arab Spring. More fundamentally, it results from the differing roles Doha and Abu Dhabi see themselves playing not just in their home region but further afield: the Al Jazeera effect vs the DP World vision. That this continues despite the breakdown of intra-Gulf relations demonstrates how deeply wedded these remarkable small states are to their respective visions of themselves as strategic actors in the wider region.

Acknowledgements Open Access funding provided by the Qatar National Library.

\section{Compliance with ethical standards}

Conflict of interest On behalf of all authors, the corresponding author states that there is no conflict of interest.

Open Access This article is distributed under the terms of the Creative Commons Attribution 4.0 International License (http://creativecommons.org/licenses/by/4.0/), which permits unrestricted use, distribution, and reproduction in any medium, provided you give appropriate credit to the original author(s) and the source, provide a link to the Creative Commons license, and indicate if changes were made.

Publisher's Note Springer Nature remains neutral with regard to jurisdictional claims in published maps and institutional affiliations.

${ }^{68}$ Gause, G. (2017) Ideologies, alignments and underbalancing in the new Middle East cold war. PS: Political Science and Politics 50(3): 672-675. 